DOI: https://doi.org/10.3126/njdrs.v16i0.31571

\title{
Agro-tourism in Nepal: A Rural Development Perspective
}

\author{
Malati Kaini \\ PhD Scholar, Central Department of Rural Development \\ Tribhuvan University, Kirtipur, Kathmandu \\ Email for correspondence: malatik2@gmail.com
}

\begin{abstract}
This library based paper presents potentiality of agro-tourism in Nepal from rural development perspective. In doing so, focuses are given to fundamentals and management of agro-tourism as well as interface between agro-tourism and rural development. This paper argues that agro-tourism not only emphasizes on good health and environment protection but also creates economic opportunities to the poor farmers, unemployed youths and women. That is why Tourism Vision 2020, Tourism Policy 2007 and National Tourism Strategy Paper (2018-34) have given more focused on rural tourism in general and agrotourism in particular. However, there are many challenges such as proper management of agro-tourism farms, road accessibility, better health care facilities and evidence based policies related to organic farming and agro-tourism marketing. Finally, this paper suggests performing different activities such as garden visit, harvesting and farm stay, farm restaurants, leisure fishing, highway landscape, agro-diversity conservation and marketing of local organic products for developing and promoting agro-tourism in more potential destinations.
\end{abstract}

Key words: Tourism, agro-tourism, rural tourism, ecotourism, rural development

\section{Background}

Nepal is known as an agricultural country with a country of the tourist destination in the world. It is a unique place for agro-tourism because of its natural beauty, varied climates and agricultural diversity. Agro-tourism is one of the alternative tourism and it, itself, is a newest form of tourism in the world, which is also known as agricultural tourism, agro-tourism, agri-ecotourism, farm tourism, farm based tourism, vacation farms, farm stays and others (Kokko, 2011). Most of the alternative tourism approaches including agro-tourism are closely related with rural economy and thereby rural development. This alternative tourism creates a new economic opportunity in rural areas and it leads to the relationship between socioeconomic development and tourism in rural areas. However, rural tourism differs from agro-tourism in two ways. First, rural tourism enterprises do not necessarily occur on a farm or ranch, or at an agricultural plant, they do not generate supplemental income for the agricultural enterprise. Second, it covers the wider arena, which includes features of various subsectors of alternative tourism such as heritage tourism, wildlife tourism, and indigenous community tourism including agro-tourism. 
Agro-tourism is "a commercial enterprise on a working farm, ranch, or agricultural plant conducted for the enjoyment of visitors that generates supplemental income for the owner." It might include outdoor recreation (fishing, hunting, wildlife study, horseback or pony back riding), educational experiences (cannery tours, cooking classes or wine tasting), entertainment (harvesting festivals, camping), hospitality services (farm stays, guided tours, catering) and on-farm direct sales (u-pick operations or roadside stands). It is a hybrid concept that merges elements of two complex industriesagriculture and travel/tourism-to open up new profitable markets for farm products and services and provide travel experiences for a large regional market. Currently, agro-tourism is experienced widely in terms of a strategy for the conservation of agricultural resources (Ceballos-Lascurain, 1996) and the allocation of economic and social benefits to the farming community (Hron \& Srnec, 2004).

Nepal has become a country of attraction for thousands of tourists every year. Regarding agriculture, though its industry is at infant stage, it is contributing more than 27.7 percent to the GDP and engaging about 60 percent (MoF, 2019) of the total population. If these two sectors are interrelated or interlinked with good integrity, the country can make tremendous economic progress in a sustainable way. In fact, farming and tourism can be the saviors of Nepalese economy in the future. Technically agro-tourist can be defined as a form of commercial enterprise that links agricultural production and/or processing with tourism in order to attract visitors onto a farm, ranch, or other agricultural business for the purposes of entertaining and/or educating the visitors and generating income for the farm, ranch, or business owner. It should include the following four factors:

- combines the essential elements of the tourism and agriculture industries;

- attracts members of the public to visit agricultural operations;

- $\quad$ is designed to increase farm income;

- provides recreation, entertainment, and/or educational experiences to visitors; and is environment friendly.

\section{Objectives}

- To highlights fundamental principle and features for managing agro-tourism development activities.

- To look at on potentiality of agro-tourism development from rural development perspective.

\section{Methods and Materials}

This is solely library based paper in which research issue are discussed based on literature reviews and empirical findings. This study is exploratory in nature that has highlighted fundamental principles and features for managing agro-tourism farm and also unpacked potential destinations producing organic products.

\section{Discussions: Fundamentals of Agro-tourism}

Like other business, agro-tourism should also be started with a plan. Before investing money, time, human resource and energy in an unconventional agricultural business as agro-tourism, new entrepreneurs should complete project feasibility and personal, financial and market evaluations. In planning an agro-tourism farm, it is necessary to understand basic principles and requirements of it. There are three agro-tourism basics: a) have something for visitors to see; b) something for them to do; and c) something for them to buy. From first two things, you cannot earn much income as other 
than a reasonable entrance fee. You can make a lot of money by organising a variety of things to sell to visitors. Research shows that tourists buy mainly food, beverages, and souvenirs. You can have a restaurant at the farm and a farm shop which sells fresh and processed food, beverages and souvenirs.

An agro-tourism attraction need not be something different than what you are already doing at your farm, the difference is that you are going to show the public what you do. Many people may start by planting a vegetable crop and offer harvesting opportunities of them in the season. Once you have identified some agro-tourism activities that seem doable, that fit with your goals and your farm resources, and that you have time for, list all the tasks or steps to get started. Once done, have someone else review it with you-call the extension or tourism office for input, or enlist the help of a business counselor or event planner if available. They may identify some details you might have missed. Research shows that tourists buy mainly food, beverages, and souvenirs. You can have a restaurant at the farm and a farm shop which sells fresh and processed food, beverages and souvenirs.

Farm tours are organised as educational tours using cropping systems and patterns and livestock as the main attraction. The aim of this farm tours is to make awareness to the visitors about the different types of crops and cultivation practices, harvesting methods and many more and different types of farm animals and animal husbandry methods as well the plight of the family farmer and create a positive image of agriculture within the visitors. Especially farm tours for school children can be organised as a concept of "re-invent agriculture" where school children obtain knowledge on real farm life.

The educational activities offered on farms range from half day classes or short-term workshops to full-scale, accredited courses of study. Farm schools accommodate interns or apprentices, and charge tuition for the learning opportunity. Some farms offer classes in cooking, arranging flowers, or making herbal medicines. They depend on these activities to help build a clientele for their main products. Farms have traditionally offered field days, sometimes sponsored by a farm organization or provincial government. Many farm tours are also considered as an educational activity. Most of these farm tours are guided by an expert in the farm and what they describe and explain is an education on the farm.

Agro-tourism attraction on your farm can be created by displaying real or models of traditional agricultural implements, techniques and technologies. Some attractions grow out of the owners' hob by collections old farm machinery and equipments, seeds of traditional crop varieties, traditional and environmentally friendly farm buildings, transportation modes, and photographs of old and traditional farming techniques and systems. Visitors like to see food processing on your farm such as milling (with traditional kurhan gala), curd, yogurt and cheese production, homemade moju, pickles and sauce production. You can make it more attractive by including processing methods and techniques with an old timely flavour that is healthier and environmentally friendly.

Organise the farm with attractive landscaping with crops and design crop arts. Most crop art consists of various designs of horticultural and grain crops (eg. maize, paddy) in a field and designs created by different coloured plantings. Such crop art is best viewed from the air or from a raised structure. There have also been proposals for creating mounds-like structures with outlined in edible native plants. Also a model home garden can be prepared and it will be attracted by the both urban and suburban visitors.

There are professional crop artists/crop land scapers and it is wise to get consultancies from such professional in planning and building crop art in your Establishing and operating a restaurant in 
the farm where one can sell cooked food from farm products and drinks is quite beneficial. Fresh fruit drinks and herbal drinks both hot and cold are good options. However, don't sell factory made artificial drinks. Fresh milk and milk products are preferred by both children and their parents. Homemade ice cream and sweets, sandwiches, fresh fruit, barbecue, and roasting fish are all possibilities for ready-toeat food sales. Traditional local food items can also be prepared and served to the tourists.

You can have a gift and souvenir shop at the restaurant premises. It is important to have your gift items represent your farm, something that is actually produced locally. Stick to a theme, something that truly represents the uniqueness of your farm and your region. Tshirts, pens, mugs, caps and hats, processed food bottles, wood carvings, pottery, and decorative items such as fresh and dried flowers and hand loomed cloths are examples of gift and souvenirs. Agro-tourism enterprise can attract two types of visitors. They are day visitors and overnight stay visitors. For day visitors, generally half a day seminar, field visit, local dance, one day / half a day product tour etc., are organized.The overnight stay on the farm can be connected with moreinterests (eg. bird watching, sport fishing, fruit picking, dancing, etc.). The owner of the agro tourism farm has to take into account the needs of potential tourists ranging from these basic requirements to something to see, something to do and something to buy. These needs can be fulfilled by properly adjusting elements of agro tourism to meet the needs. Among these elements organization of accommodation on the proper level, attractions of environment, accessibility of every-day facilities and forms of spending the leisure time are very important. Hospitality is the most important intangible asset required for your agro-tourism business.

\section{Management of Agro-tourism}

If anyone wants to establish and run agro-tourism business he or she will have to fulfil some basic physical requirements in the first instance.Agricultural farm unit in agriculture is the basic production. A farm which introduced a new section into its structure, agro-tourism is called an agrotourism farm. Agro tourism farm produces plant and animal products and offers service in agro-tourism. The both sections on an agro tourism farm agriculture and tourism is dependent on the other. Often the farm production depends partly or fully on tourism and vice versa, for example tourists eat food produced on the farm and the objective of a tourist to visit a farm to experience quiet farm life. The amount of income from a given section depends from one another and can be different.

On a pure agriculture farm 100 prcent of income comes from plant and/or animal production as well as food processing. On an agro-tourism farm part of the income comes from tourism and the rest from the farm production. The ratio of agro-tourism income in total income of the farm shows the meaning of agro-tourism for that farm. The more income comes from agro-tourism, the more important it is for the farm. In agro-tourism farms a reasonable amount of the land used for buildings, car-parks, lawns and flower-beds to make the area more attractive. Water sources are used to create water features for recreation. The way of managing agro tourist farms is sometimes different from other farms. For instance, general farms try to specialize the production focusing often on one kind of production, while for the agro-tourism farms diversification is better because this way it is more attractive for tourists.

The agro-tourism farms try to make their production more extensive and ecologically/ environmentally clean because these meet the needs of the tourists/visitors. In Nepalese context local farmers having informal education or indegineous knowledge are producing ecologically and environmentally clean products to the guests. Pasa and Adhikari (2019) also reveal insignificant 
relationship between the educational status of the respondents and promoting the local products for ecotourism development in Sundarijal and Mulkhark settlements located in Shivapuri Nagarjun National Park. The respondents, whose academic qualification is less than grade 10, are more conscious of this matter. They want to please the tourists by locally grown agriculture, dairy products, and ethnic food, costumes, and dresses. The general farms try to introduce as much technical development as they can aim for higher production. However, these modern techniques used in farm production are not very attractive for agro tourists. The traditional and indigenous methods of agricultural production are of great importance for the agro-tourism. They were different in different countries and even different regions. Agro-tourism farms accept technical development only in the field of improving tourist service. The angle at which the agro tourism farms look at the market is also different. The market is very important and agro-tourism farms consider tourists and visitors as their main market segment.

In establishing an agro-tourism farm (starting a new farm from beginning or converting an existing farm) you have to bear three types of costs. They are establishing costs, property costs and production costs. Establishing costs is the cost incurred in purchasing a land, fencing, and construction of buildings, water tanks, bans, electricity supply, inner roads, and other similar things.Property costs are the costs, which must be paid even if the farm does not produce goods. It is obligatory to pay taxes and payments, paint the building or repair damages. Even there is no farm production or agro-tourism activity, owner has to bear some cost and this is property cost. Costs connected with producing goods and services are production costs. This cost includes both cost for agricultural production and agro tourism. Ways of Managing Agro-tourism farm are as shown below (Table 1).

Table 1. Ways of Managing Agro-tourism Farm

\begin{tabular}{ll}
\hline $\begin{array}{l}\text { Activities } \\
\text { Land Usage }\end{array}$ & $\begin{array}{l}\text { Features of Managing or Doing Activities } \\
\text { Use part of the land for the agricultural production (crops and livestock), } \\
\text { and rest for tourism (cabanas, restaurant, car parks, farm shop, therapy, } \\
\text { etc.) } \\
\text { Farming activities serves agro-tourism; crop and livestock diversification; } \\
\text { balanced development of the farm }\end{array}$ \\
production & $\begin{array}{l}\text { Local practices are followed for production of agriculture tourists are } \\
\text { encouraged to participate. } \\
\text { Way of production }\end{array}$ \\
Extensive production and protection of the environment; preferably \\
organic farming; optimal usage of the agro-tourism area
\end{tabular}

(Sznajder \& Przezbórska, 2004)

Nepalese Journal of Development and Rural Studies, Volume 16, 2019 


\section{Interface between Agro-tourism and Rural Development}

Agro-tourism is closely related with rural life and nature and has direct relationship with the economicactivities. It has four types of impacts-economic impact, cultural impact, environmental impact and social impact. Among these 4 impacts, the economic impact is the most visible. If tourism of any place is supported by the local agricultural production, change in income and employment generation can be seen first. Crops, especially fruits, vegetables and ornamental plants are environment friendly for the hilly areas. Gardens and landscapes can reflect culture of the place if due attention is given in their design. Sharing of gardens and landscapes through visit by many tourists can also have social impact of different types. In many countries including Nepal, the economic gap between rural and urban populations is widening on a daily basis. Likewise, the rural population is decreasing and profitability in agriculture is also declining mainly due to many reasons. Under such circumstances, sustaining the rural economy, which is a largely agriculture-driven endeavor, presents great challenges and demands proactive actions.

In the quest to revitalize the rural economy, Japanese, economist, Naraomi Imamura (1998) proposed a new model of rural development in 1998 called 'Sixth Industrialization'. The 'Sixth Industrialization' is the convergence of primary industry (agriculture production), secondary industry (processing and manufacturing) and tertiary industry (service sector). In other words, it is hybridizing the primary, secondary and tertiary industries and creating a new industry. 'Sixth Industrialization' encourages the utilization of locally available natural resources, traditional technologies, people's talents, and incorporation of history and culture. Agro-tourism can well be fitted in this model of rural development. Nepal has tremendous traditional knowledge and technology related to agriculture. The popularity of home stay and agro-tourism is gaining momentum in Nepal. So integration of tourism with agriculture has tremendous scope to boost rural economy and rural development process. In the reference of Chaudhary and Pasa (2015) rural development process seeks to alleviate poverty, mass utilization of resources, commercialization of agriculture, food security, creating opportunities, infrastructural development of rural community and modernization of the society.

More so, integrating farming with tourism can provides many benefits to the local communities (Figure 1). Some of the benefits are: creation of new jobs and providing employment; creation of new markets for local products; increase in land productivity; contribution to establish agro-based industries; establishing linkage between urban community and rural people; and improving livelihood of the local community. Agro-tourism is a kind of eco-tourism which is expanding around the world. Greece, Poland and China are the leading countries for agro-tourism integration.

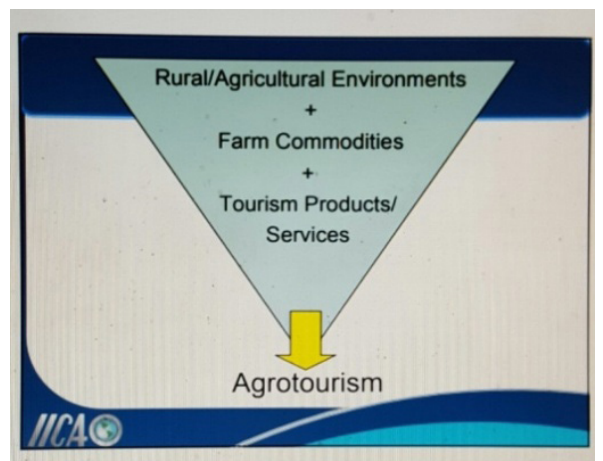

When people link travel with

products and services, it becomes an economic activity. Activities of tourist attraction related to agriculture can be garden visit, harvesting and farm stay, farm restaurants, leisure fishing, highway 
landscape, agro-diversity conservation and marketing of local produce. Regarding harvesting and farm stay, many tourists like to harvest fresh fruits and enjoy eating them fresh in the orchard. If they get an opportunity to stay overnight in the horticulture farm enjoying with the fresh products, it will be wonderful experience to them. In thewell-established trekking routes of Nepal, such as Kathmandu to Namche, Kathmandu to Pokhara to Jomsom etc., it is quite feasible to establish horticulture farms with this noble objective. In Gorkha and Mustang district, some private horticulture farms are taking economic benefits from such type of practices since long time. If any entrepreneurs want to establish horticulture farm along the tourist route with such objectives, the government should promote it by providing policy and other supports.

\section{Agro-tourism in Nepal: Policy Perspective}

Broadly speaking the current priorities of Nepalesetourism are shaped by Tourism Vision 2020, Tourism Policy 2007 and Nepal Tourism Year 2011. NTB aligns its annual programs and activities to match the priorities and new initiatives of the government and the aspirations of private sector. The Nepal Tourism Year 2011 targeted one million annual IVAs by 2011 and 40 percent IVAs were dispersed to new tourism areas. Investment in tourism was increased and domestic tourism was promoted. The Tourism Policy 2007 has recognized leading role of Private Sector in Tourism. More focus has been given on public-private partnership (PPP) approach and emphasis has been given on rural tourism, community based tourism and home-stays. Two committees namely Tourism Coordination Committee and Crisis Management Committee have been formed and the Tourism Council (Apex body chaired by the PM) has been activated. The Tourism Vision 2020 has been developed with the following vision, goals and objectives:

Vision. "Tourism is valued as the major contributor to a sustainable Nepal economy, having developed as an attractive, safe, exciting and unique destination through conservation and promotion, leading to equitable distribution of tourism benefits and greater harmony in society".

Goals. Increase annual international arrivals to Nepal to 2 million by 2020; Expand economic opportunities and increase employment in tourism sector to 1 million by 2020 .

Objectives. To improve livelihoods of the people across the country by developing integrated tourism infrastructure, increasing tourism activities and products, generating employment in the rural areas enhancing inclusiveness of women and other deprived communities, and spreading the benefits of tourism to the grassroots level; To develop tourism as a broad-based sector by bringing tourism into the mainstream of Nepal's socioeconomic development, supported by a coherent and enabling institutional environment; To expand and extend tourism products and services in new and potential areas of Nepal by enhancing community capacity to participate in tourism activities; To publicize, promote and enhance the image of Nepal in international tourism source markets; To enhance the flight safety and aviation security, extend air connectivity, and improve capacity and facilities of national and international airports and; To attract new investment in creating new tourism facilities, products and services.

Strategies. Improving Livelihoods and Spreading Benefits at the grassroot levels; Economic Mainstreaming; Expanded Product Offering; Destination Marketing; Aviation; Attract New Investment. 
The national tourism policy in Nepal-1995 has prioritized on diversifying tourism to rural areas through agriculture and domestic cottage industries to enhance the national economy.Sometimes people get confused with the following three types of tourism. But their main characteristics are different as shown below (Table 2).

Table 2. Characteristics of Three types of Tourism

\begin{tabular}{lll}
\hline $\begin{array}{l}\text { Rural Tourism } \\
\text { Tourism that take place in rural } \\
\text { areas or communities. }\end{array}$ & $\begin{array}{l}\text { Agro-tourism } \\
\text { Activities of tourism } \\
\text { directly related to } \\
\text { agriculture. }\end{array}$ & $\begin{array}{l}\text { Ecotourism } \\
\text { Tourism which is nature based } \\
\text { form whose main motivation on } \\
\text { the observation and appreciation } \\
\text { of nature as well as the traditional } \\
\text { cultures prevailing in natural areas. }\end{array}$ \\
$\begin{array}{lll}\text { Establishments by mall family } \\
\text { owned and practice from there }\end{array}$ & $\begin{array}{l}\text { A farm or household led } \\
\text { practice as a source of } \\
\text { income }\end{array}$ & $\begin{array}{l}\text { Small locally owned businesses is } \\
\text { from Service providers }\end{array}$ \\
$\begin{array}{l}\text { Natural areas, local practices, } \\
\text { culture and gastronomy are } \\
\text { highlighted }\end{array}$ & $\begin{array}{l}\text { Highlighting and } \\
\text { explaining aspect of } \\
\text { agricultural lifestyle aimed } \\
\text { by educational activities }\end{array}$ & $\begin{array}{l}\text { Educational and interpretation } \\
\text { features there increasing awareness } \\
\text { towards the conservation of natural } \\
\text { and cultural assets. }\end{array}$ \\
$\begin{array}{l}\text { The tertiary sector of economy } \\
\text { is having independent } \\
\text { activity integration, mass } \\
\text { tourism is having alternative } \\
\text { complementary form }\end{array}$ & $\begin{array}{l}\text { integrated with agro- } \\
\text { tourism }\end{array}$ & $\begin{array}{l}\text { Described as niche tourism, differ } \\
\text { from the rural tourism by the } \\
\text { closeness to nature and the more } \\
\text { rational exploitation of tourism } \\
\text { resources. }\end{array}$ \\
$\begin{array}{l}\text { Natural lovers are taken as } \\
\text { potential customers }\end{array}$ & $\begin{array}{l}\text { Interested in farming and } \\
\text { agricultural products are by by } \\
\text { potential customers }\end{array}$ & $\begin{array}{l}\text { Meaningful community participation, } \\
\text { slow travel, and high quality } \\
\text { experiences are upon interest by } \\
\text { potential customers. }\end{array}$ \\
\hline
\end{tabular}

(National Tourism Policy, 1995)

It believes that agro-tourism allows tourists to be in close contact with the inhabitants of small rural villages being involved in traditional way of agriculture. It can find out how food grains are harvested, sorted and preserved, how vegetables can be grown organically, how freshly picked fruits are turned into delicious marmalades, how cows, buffaloes, goats are milked, cheeses are made, and so on. At the same time, it mobilizes the productive, cultural and developmental forces of an area, contributing in this way to the sustainable environmental, economic and social development of the rural area. Agritourism, itself, is a newest form of tourism in the world, which is also known as agricultural tourism, agrotourism, agri-ecotourism, farm tourism, farm based tourism, vacation farms, farm stays and others (Kokko, 2011).

But we need to develop the skilled human resources in both agriculture and tourism sectors. So, it is important to incorporate agro-tourism in formal and information education, research and training (Maharjan, 2014). Despite one university and many agricultural colleges in Nepal, none of them is focusing onagro-tourism education in Nepal. In the context of research, Dangol (2005) emphasized on intense and dedicated research and analysis in agro-tourism research work. Furthermore, he highlighted on targeted researches on agro-tourism and also in combination with other forms of tourism. 


\section{Potentiality of Agro-tourism Development in Nepal}

Organic products. In rural areas it's been found in some areas, organic farming going on. The model of organic agro-tourism has similar characteristics to traditional agro-tourism enterprises except that it emphasizes more on health and protection of environment and natural resources. It is the next big thing in global tourism market. By certifying our tourism areas organic, we can bring high-end tourists from all over the world here. As the farming technique in the rural areas of Nepal is already organic by default and hence, we only need to brand it and promote it effectively in the international market. Even today, many kinds of organic products are found in different parts of the country (Table 3).

Table 3. Organic Products in Different Places of Nepal

\begin{tabular}{ll}
\hline Places & Organic Products \\
Bajura & Sea buckthorn juice \\
& Olive oil \\
Dolpa, & Apples \\
Humla & Beans \\
Ilam & Organic tea \\
Jumla & Beans \\
& Walnut \\
Manang & Marsi rice \\
Mustang & Apples and buckwheat \\
Tanahun & Apples \\
& Hill lemon \\
& Jackfruit \\
& Mandarin orange \\
& Black gram \\
Western Tarai & Fern \\
\hline & Yam \\
\hline
\end{tabular}

(DoA, 2019)

Furthermore, more jobs can be created through organic agriculture which is more laborintensive than their pesticide and chemical fertilizer-using equivalents. If organic agriculture integrates with tourism, organic farmers and tourism entrepreneurs will foster their incomes lucratively. This could also help retain youths in farming profession. In order to harness the joint potential of tourism and organic agriculture we need to include the following programs:

- Raising awareness and building capacity to attain a better understanding of the linkages between tourism and agriculture.

- Establishing public-private partnerships with destination stakeholders as key components in the implementation of pro-poor tourism practices. This strategy relies on collective commitment, strategic partnerships, effective institutional arrangements and facilitating processes.

- Promoting pro-poor tourism and branding. This strategic theme focuses on the need to promote tourism products, experiences and destinations in Tanzania that benefit local people through effective and robust marketing plans and branding. 
Agro-tourism destinations. Tourism routes including agro-tourism have been mushroomed all over Nepal in recent years. This is because they offer important dispersal and product development opportunities and at the same time fall in line with visitors increasingly wanting to experience new things. Evolving tourism trends have led to a shift away from standardized mass tourism to more individualistic patterns in which greater flexibility and a more meaningful experience have gained prominence (Poon \& Gilbert 1989). It has been argued that rural tourists have a wide range of motivations, from ecological uniqueness, special adventure opportunities, cultural attractions or the peace and quiet of the countryside. Routes, however, vary considerably in length and scale. Many routes that are developed in Nepal with particular interest to international tourists have high potential for developing agro-tourism. The government of Nepal has specified 100 new tourism destinations for promoting rural tourism. It is said that these destinations will be well equipped with the transportation, logistics and other basic fundamentals. Furthermore, these destinations will also help promote agrotourism.

Packaging. Agro-tourism development takes place in an integrated manner and can take advantage of many added extras and be sold as one product. The packaging of an agro-tourism experience requires more work in the planning stages but has potential to attract more customers. An example of packaging of the agro-tourism product could be a collective effort whereby the agro farm is one of many destinations within a local tour. The farm products could be highlighted at the farm entrance and presented for lunch at the farm restaurant. Different farm operators can work together to package their products to form a basket of agro-tourism products for tourists. A stay at a farm Bed and Breakfast can include admission to the local agricultural fair, a harvesting festival, and a local guided tour. Also honeymoon packages can be designed to be part of a cottage with Bed and Breakfast stay where the newly wedded couple can get memorable experience.

\section{Prospects and Challenges of Agro-tourism}

Prospects. The primary direct target beneficiaries are the poor farmers, unemployed youths and women mainly engaged in small scale agriculture activities. In the present context, only few people who are directly engaged in hotel/restaurant business and tour guides are mainly grasping the benefits from the tourism sector. With the implementation of the agro-tourism programs the farmers and marginalized people residing in the periphery of the trekking routes will be benefited mostly. Besides, these people the hotel/restaurant owners, staff working with these hotels/restaurants and other entrepreneurs like bakery owners will also receive the benefits. The local environment will be further conserved with the introduction of organic farming and substitution of packaged food items. Moreover, it brings visitors closer to nature and rural activities in which they can participate, be entertained and feel the pleasure of touring, learning and discovering. However, the primary objective of ecotourism should be to protect the natural environment of the rural areas and stop the negative impact of human development. When local communities realize the benefits of agro-tourism, it will encourage them in the conservation of these areas. Support from the local government is critical, and it should provide the necessary funds to these places to maintain their economic growth through agriculture, which will benefit the overall economy of the country.

Agro-tourism may contribute to the stability of the green industry in any country. It may help to improve farm viability by increasing the commercial possibilities through both direct sales 
of crops and livestock products and other business accommodations and by adding value to regional landscapes. Agro-tourism is an excellent means of supporting rural communities. Tourists bring rupees to local communities that keep rural communities alive and prosperous. The partnering of tourism and the green industry will help create and strengthen rural economies. Agro-tourism is an opportunity to increase agricultural awareness among the public and to promote fresh farm products. It also provides opportunities to increase consumers' understanding of the environmental horticulture industry. The interaction of tourists with nursery or greenhouse activities or crops carries an educational aspect. Tourists tend to enjoy learning about items and processes that they will not participate in directly. A guided walking tour of a garden center or nursery will help children learn the basics of how plants grow, and learn what a farmer's job comprise of. They will start to respect both farmers and farming. They will see the farm equipment, learn about cultivation and animal rearing and will understand the importance of preserving farmland as open space for the future.

Agro-tourism can be connected with health services or health-related products (Sznajder \& Przezbórska, 2004). Tourists approaching to the countryside may expect the possibility of a specific therapy, e.g. special diet therapy, including consumption of "healthy" products. Also the visitors like to consume food prepared by using firewood instead of gas or electricity. Not only that they prefer to consume food prepared in clay pots instead of metal pots. All these are connected with diet therapy. Other than farm products they like to consume dishes made out of local crop varieties. There are lot of medicinal values in these local crop varieties that cannot be found in urban areas. Also, there are specific wild crop varieties and food items prepared in different localities. Having fresh vegetables, fruits, meat and other food items makes a person mentally satisfy and it is a mental therapy for a person.

Further, in addition to diet therapy, visitors can be arranged with other types of therapy such as fish therapy, indigenous medicinal (ayurvedic) therapy, foot therapy, yoga or meditation, etc. Fish therapy is very famous within the visitors in countries like Malaysia. In Sri Lanka also fish therapy can be introduced with agri tourism, especially if you have a stream flows in the farm or closer to the farm.

Challenges. As Nepal is a mountainous country, it is easy to figure out that the first and foremost challenges of agro-tourism must be the transportation. Also on the list of one of the least developed countries in the world, Nepal has no facility of road transportation reaching to all rural settings. The author of the article had heard from her Nepali friends that products produced in one part of the country cannot reach the other part because of the lack of infrastructure. Apple grown up in the Himalayan region rot out there because there is no way they could be brought to the cities, but people living in big cities have to import apples from India. In this situation, how can tourists reach the remote Nepal to witness its beauty and experience its authentic culture and agriculture? During May and Juneof 2013, three plane crashes occurred in Nepal, raising serious questions about the country's civil aviation security and the safety of passengers, most of whom are foreign tourists. These kinds of news obviously scare the tourists away. Most of the foreigners would not trust the domestic airlines in Nepal. Most of the planes crash in High Mountain and hilly regions on the way to remote places, which means that these plane crashes are a very big challenge for rural tourism.

Communication and electricity are other integral components for the development of agro- tourism. Lack of infrastructure and development definitely means that there is no facility of 
communication like internet and telephone in all the rural parts of Nepal. According to BBC news, despite the massive hydropower potential, Nepal only produces about half of its electricity need. Less than half of the population is connected to the Nepal power grid and power has to be imported from India. A lack of favorable policies to encourage links between agriculture, tourism and trade is also a major challenge in Nepal.

Another challenge for the development of agro-tourism in Nepal seems to be the people themselves. They have the traditional belief that agriculture could be the only source of income to the rural people and they have off let realization of the fact that tourism can also play an important role in development process. With 65.9 percent literacy rate in total population (CBS, 2019), and the majority of remaining illiterate population living in the rural areas, it is very difficult to make them understand the importance of agro-tourism to them and the country. Their rooted traditional belief and led back nature is hard to change. On top of that the absence of supporting industry and proper legislation system kills the idea of agro-tourism right at the initial stage. The author has mentioned earlier that younger generation and the work force of the rural villages are moving to the big cities and foreign countries in search for work. Villages in Nepal are full of old people and lack manpower. Financial support remains at the top of the list.

\section{Conclusion}

Four hundred sixty rural municipal areas of Nepal (GoN, 2015) is the nice place for the development through agriculture and tourism. Proper activeness of rural people within agro-tourism will certainly give the great chance of making the rural economy sound. Due to this activity, more nice linkage with urban areas will be in the name of socio-economic development. The trend of use of local seeds, saplings, manure by local rural people with bit modernity will let the development of agro-tourism in the name of tourists' attractions towards farmlands. Beyond doubt, in the rural areas of Nepal agro-tourism will certainly workout for uplifting the economic status. As agriculture is Nepal's main economy, best self-enrollment of rural people, returnees, and interested urban people within rural farming areas will let the agriculture sector developing through more attraction propaganda for the tourists to be in soon by. This type of scheme will be supporting for the minimization of local people towards third countries as employment will surely be through agro-tourism in their rural homelands. Thus best binding of all the rural groups in rural farmland areas will support for the needed development of agro-tourism. Agro-tourism will certainly support for the nice rural development scheme by letting the good collaboration with urban centers for nation's development.

\section{References}

Central Bureau of Statistics (CBS). (2019). Literacy rate of Nepal. Kathmandu: Government of Nepal.

Ceballos-Lascurain, H. (1996). Tourism, ecotourism and protected areas. Gland, Switzerland: International Union for Conservation of Nature.

Chaudhary, P. K. \& Pasa, R. B. (2015). Agriculture Education for Rural Development in Nepal. Journal of Training and Development, 1, 38-45. Author. doi: https://doi.org/10.3126/jtd. v1i0.13089

Dangol, D. R. (2005) Agritourism development in Chitwan: Prospects, challenges and opportunities. Chitwan, Nepal: District Development Committee. 
Department of Agriculture (DoA). (2019). Annual report, 2018. Kathmandu: Author.

GC, A. (2019). Changing track. Kathmandu: Kathmandu Post.

Gilbert, D. (1989). Rural tourism and marketing: Synthesis and new ways of working. Tourism Management, 10(1), 39-50.

Hillary, G., \& Rilla, E. (2011). Agritourism and nature tourism in California. California: University of California, Department of Agriculture amd Natural Resources.

Hron, J., \& Srnec, K. (2004). Agrotourism in the context with the rural development. Czech, Praque: University of Life Sciences.

Imamura, N. (1998). Sixth industrialization for aquiculture to create additional values. 21 Seiki Murazukurijyuku, 1-28

Kokko, A. (2011). An exploration of agritourism: Topics, literature and areas for future research.

Maharjan, S. K. (2014). Development and promotion of the agrotourism in Chitwan. Chitwan, Nepal: Lambert Academic Publishing.

Maria-Irina, A. (2017). Ecotourism, agro-tourism and rural tourism. Conference paper presented on contemporary approaches and challenges of tourism sustainability at Predeal, Romania. Romania: Bucharest University of Economic Studies.

Ministry of Finance (MoF). (2019). Economic survey. Singhadurbar Kathmandu: Government of Nepal.

NAKANO, K. (2014). The "sixth industrialization" for Japanese agricultural development. The Ritsumeikan Economic Review, 3(LXIII). Japan:

Neupane, S., \& Thapa, C. (2013). 'Underwriter reputation and the underwriter-investor relationship in international union for conservation of nature initial public offering markets'. Journal of International Financial Markets, Institutions and Money, 24.

Pasa, R. B. \& Adhikari, D. (2019). Ecotourism in changing the lives of bufferzone People: The case from Shivapuri Nagarjun National Park, Nepal. IOSR Journal of Humanities and Social Science (IOSR-JHSS), 24(10), 14-22. doi: 10.9790/0837-2410101422

Poon, A. (1993). Tourism, technology and competitive strategies, Wallingford: CAB International.

Mahaliyanaarachchi, R. P. (2014). Agro-tourism. Sabaragamuwa: University of Sri Lanka. Faculty of Agricultural Sciences.

Sznajder, M., \& Przezbórska, L. (2004). Identification of rural and agri-tourism products and services, Roczniki Akademii Rolniczej WPoznaniu-Ccclix, 165-177. Poznań: Cieszkowski Agricultural University.

World Economic Forum (WEF). (2013). Travel and tourism competitiveness report. Cologny, Geneva: Author. 